\title{
VEGETAÇÃO E ENSINO DE PAISAGISMO: UMA EXPERIÊNCIA DE SENSIBILIZAÇÃO
}

\author{
VEGETATION AND LANDSCAPING TEACHING: \\ A SENSITIZING EXPERIENCE
}

\author{
Ana Carolina Carmona Ribeiro
}

\begin{abstract}
Resumo
O presente trabalho é uma reflexão sobre um conjunto de experiências realizadas junto aos estudantes do curso de Arquitetura e Urbanismo do Instituto Federal de São Paulo, nas disciplinas de desenho artístico e paisagismo - experiências nas quais tentamos estabelecer uma abordagem de ensino ligada aos conceitos de Planejamento Ecológico e Infraestrutura Verde, ao invés de abordagens meramente ornamentais da arquitetura paisagística. O objetivo principal foi o de despertar nos alunos o interesse pelas dimensões biológicas, espaciais e sociais da vegetação, em um contexto em que a chamada Cegueira Vegetal (Plant Blindness) é cada vez mais comum. Tais experiências exploraram o desenho como ferramenta de apreensão das características das espécies e de superação da visão de que "todas plantas são iguais". Foram propostos três eixos temáticos, cada um deles trabalhando questões específicas em relação à vegetação: em "As árvores e a cidade", estudou-se a diversidade de árvores e palmeiras na arborização urbana de São Paulo; em "Plantas no jardim", foi trabalhado o conhecimento prático sobre o plantio como fundamental para o paisagismo; já "Vegetação e biomas" propôs uma compreensão das plantas em seu ambiente natural e em suas relações com outros elementos bióticos e abióticos, assumindo a centralidade da perspectiva ecológica para o paisagismo. As principais ações envolvidas nessas experiências foram descobrir, reconhecer e experimentar o verde - promovendo uma relação mais sensível entre sujeito e objeto, na qual o engajamento permitiu aprofundar o conhecimento sobre a flora e surgiu como fator determinante para a formação dos futuros arquitetos paisagistas.

Palavras-chave: Ensino de paisagismo. Vegetação. Sensibilização. Desenho.
\end{abstract}

\begin{abstract}
This article develops a reflection on a set of experiences carried out alongside drawing and landscape design students of the Architecture and Urbanism course at the Federal Institute of São Paulo. Through these experiences, we attempted to establish a teaching perspective premised on the concepts of Ecological Planning and Green Infrastructure $(\mathrm{Gl})$, rejecting approaches to landscape architecture that are mainly concerned with ornamentality. Considering that Plant Blindness is increasingly common, our main goal was to raise students' sensitivity and awareness towards the biological, spatial and social dimensions of vegetation. Thus, these experiences explored drawing as a tool for the apprehension of the characteristics of each species and for overcoming the all-too-common view that "plants are all the same." Three thematic axes were proposed, each presenting specific questions regarding the presence of urban vegetation: "The tree and the city" studied the diversity of native trees and palm trees in São Paulo's urban forestry; "Building a garden" pointed out that practical knowledge on planting is fundamental to landscaping; "Vegetation and biomes" proposed an understanding of plants in their environment and in their relationships with other biotic and abiotic elements, recognizing that the ecological perspective is paramount for landscape design. The main actions involved in these activities were discovering, acknowledging and experiencing the green. This fostered a more sensitive relationship between subject and object, in a form of engagement that led to deeper knowledge about vegetation, regarded as a determining factor in the training of future landscape architects.
\end{abstract}

Keywords: Landscaping teaching. Vegetation. Sensitizing. Drawing. 


\section{INTRODUÇÃo}

O presente trabalho é uma reflexão sobre um conjunto de experiências realizadas junto aos estudantes do curso de Arquitetura e Urbanismo do Instituto Federal de São Paulo, nas disciplinas de paisagismo e desenho artístico. Nessas experiências, o ensino foi pensado em estreita ligação com as estratégias ecológicas da Infraestrutura Verde - na qual a vegetação tem um papel que vai muito além da função ornamental, como normalmente ocorre no paisagismo convencional.

Primeiramente, é importante situar brevemente o contexto em que o trabalho foi desenvolvido e as dificuldades com as quais ele precisou lidar. A formação da mentalidade brasileira em relação à natureza foi enormemente influenciada pela Guerra Verde, expressão utilizada pelo historiador Nicolau Sevchenko para sintetizar a luta pelo controle e dominação da natureza do Novo Mundo por parte do colonizador europeu, tendo em vista a obtenção de riquezas vegetais. Desde o século XVI, e ainda hoje (como demonstram as
Quando são deixados aqui os primeiros homens brancos europeus (...) eles olham e não há mais nada que os ligue à Europa, e pela frente o que veem é só mata verde. Da mata verde surgem as feras, da mata verde surgem os insetos, da mata verde surgem os índios, e todo o perigo. E se eles estão ali para conquistar alguma coisa, só podem ver o que há para conquistar se a mata sair da frente. Portanto a melhor paisagem do ponto de vista de quem está na posição do colonizador (...) é a paisagem ausente, é a eliminação completa daquele verde. Porque o verde é o perigo, a possibilidade iminente de sua extinção física. Nessa direção é que se constrói a lógica da ocupação predatória

1 As queimadas na Amazônia recentemente ganharam destaque nos noticiários do mundo inteiro, mas outros biomas brasileiros, como o Cerrado, estão igualmente ameaçados. 0 que acontece hoje é apenas mais um capítulo da destruição iniciada com a colonização, e enormemente ampliada a partir do século XIX - quando a maior parte da Mata Atlântica foi devastada em queimadas que duravam meses e escureciam o céu do Brasil, exatamente como tem acontecido agora (o livro de Warren Dean é referência fundamental nesse sentido). da terra e é assim que se desenvolve a sensibilidade nativa com relação à natureza (SEVCHENKO, 1996, p. 111).

Historicamente, tal sensibilidade - que, por vezes, se aproxima da absoluta falta de sensibilidade, e, por outras, de uma sensibilidade postiça, em que a natureza brasileira é idealizada, como na literatura e na pintura do Romantismo brasileiro, no século XIX - ignorou a sabedoria das populações nativas em relação à natureza e às relações do homem com os outros seres vivos; no que se refere à vegetação, por exemplo, segundo Flávio Motta (1986, p. 4) o antropólogo Lévi-Strauss notou que, enquanto os índios brasileiros conheciam e se utilizavam de mais de $90 \%$ das espécies da flora local, o colonizador fazia uso de apenas uma pequena fração dela. Como se pode imaginar, tal ignorância só veio a aumentar nos cinco séculos de existência do Brasil, culminando no atual estado de coisas; um estado em que a ocupação predatória da terra se tornou a regra, seja nas cidades - com a expansão da pobreza e a especulação imobiliária -, seja no campo - onde a soja e a pecuária vêm implicando na perda de biodiversidade e na desertificação de grandes áreas no interior do país (Figura 1).

Tal quadro, sem dúvida, tem relações com o fenômeno que Wandersee e Schussler (1999, p. 82) nomearam como Plant Blindness, e que atinge grande parte do mundo ocidental-urbanizado: a dificuldade de perceber as plantas em seu próprio ambiente, que leva à incapacidade de reconhecer sua importância na biosfera e para os assuntos humanos; à incapacidade de apreciar suas características biológicas e estéticas singulares; e à classificação antropocêntrica das plantas como seres inferiores aos animais, levando à conclusão errônea de que elas não merecem a consideração humana. Esse fenômeno pode ser encarado como uma confirmação científica de algo que já havia sido intuído há décadas, por paisagistas como Roberto Burle Marx (1909-1994) - que, assumindo uma postura crítica frente à destruição do meio-ambiente e ao crescimento desordenado das cidades brasileiras, identificou que, para muitas pessoas, as plantas seriam "simplesmente mato", revelando o desconhecimento e mesmo o desprezo da população em relação à flora nativa. Ele também se relaciona, como não poderia deixar de ser, com a situação do ensino de botânica; em geral, o tema costuma 


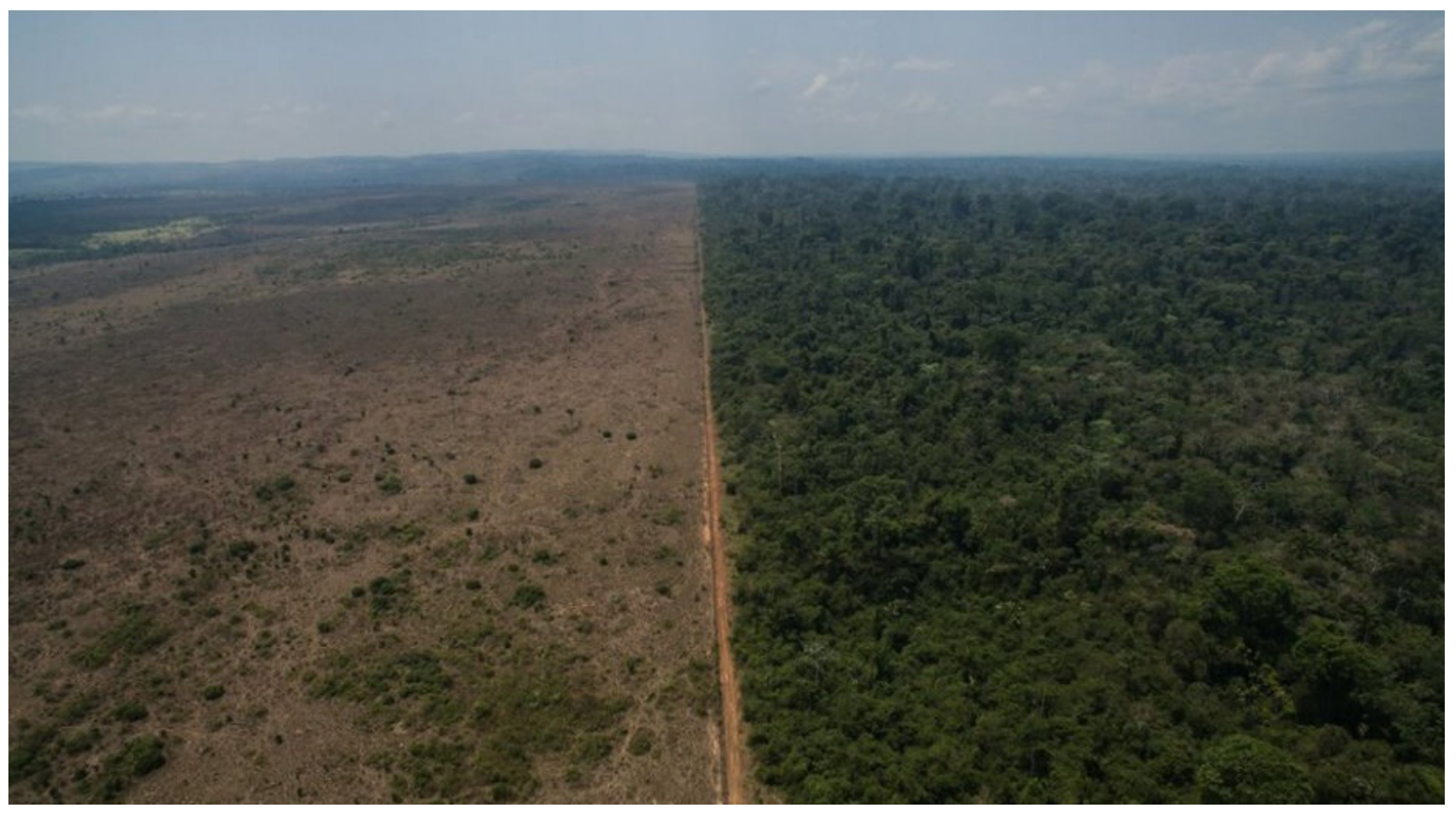

Figura 1 - Contraste entre a terra indígena Mebengokre e território não demarcado. Fonte: Simone Giovine (Associação Floresta Protegida).

ser abordado muito superficialmente nas escolas, reduzindo-se a uma enumeração de nomes a serem memorizados e que logo serão esquecidos, como relatam Silva et al. (2016, p. 69) - sem que se associe o que é aprendido em sala de aula ao cotidiano².

Como reagir a esse quadro desalentador? Os autores chegam a conclusões parecidas, cogitando alguns caminhos possíveis: a pesquisa científica, a exemplo dos estudos que vêm apontando que os vegetais poderiam ter consciência e inteligência ${ }^{3}$; a realização de mudanças no ensino fundamental, com mais aulas práticas e experimentais sobre o assunto; a criação da figura de um "mentor

2 A esse respeito, em depoimentos acerca de suas próprias experiências em relação à botânic na escola, os estudantes deixam bem clara essa falta de conexão. Uma delas relata: "Era só decoreba. Tinha muita árvore e muita planta na escola, mas não levavam a gente para ve as coisas de perto"

3 A neurobiologia vegetal, por exemplo, pretende entender como as plantas processam as informações que obtêm do ambiente para se reproduzir e prosperar; a partir disso, avança inclusive para o campo da ciência aplicada, como na parceria entre o International Laboratory of Plant Neurobiology (LIV) e a Agência Espacial Europeia, que vêm buscando desenvolver tecnologias inspiradas nas formas, sistemas e funções vegetais, como relata o fisiologista italiano Stefano Mancuso em seu livro Revolução das Plantas (2019). botânico" (plant mentor) que desde cedo ajudaria a despertar nas crianças o interesse pelas plantas; o incremento dos jardins botânicos; ou, ainda, como propunha Burle Marx, a transformação do próprio projeto paisagístico em um recurso para que a população aprofunde seu conhecimento sobre a flora, por meio da "participação na paisagem" (MOTTA, 1986, p. 5).

\section{Materiais e métodos}

As experiências aqui relatadas são parte de um esforço de reflexão e mesmo de tomada de posição em relação a este quadro que acabamos de expor, realizado no contexto específico de um curso de Arquitetura e Urbanismo, no qual, dentre outras competências, trabalha-se a formação dos futuros arquitetos paisagistas ${ }^{4}$. 0 artigo,

4 No Brasil, o paisagismo não é profissão regulamentada - sendo exercido por jardineiros, horticultores, agrônomos, botânicos, artistas e arquitetos. Nesse último caso, o Conselho de Arquitetura e Urbanismo (CAU), junto com a Associação Brasileira de Arquitetos Paisagistas (ABAP), têm defendido o paisagismo como atribuição exclusiva do arquiteto, o que tem causado polêmicas entres os vários profissionais atuantes, esbarrando também nas limitações de carga horaria das disciplinas de paisagismo nos cursos de arquitetura. 
assim, deve ser entendido como uma tentativa inicial de registro e sistematização de exercícios realizados de forma bastante intuitiva, apoiando-se em larga medida na experiência docente cotidiana e valorizando o protagonismo dos alunos. No horizonte deste trabalho, está a intenção de repensar o ensino de paisagismo a partir de novas abordagens teóricas e práticas, assim como de novas estratégias projetuais; a sistematização e o aprimoramento dessas experiências poderia, quem sabe, contribuir para a formulação de novas metodologias a serem adotadas em outras instituições de ensino e mesmo mais amplamente junto à população.

Para maior clareza metodológica, no presente artigo, os vários exercícios realizados foram reunidos em três grupos principais: "As árvores e a cidade" (que envolveu o estudo das árvores e palmeiras utilizadas na arborização urbana), "Plantas no jardim" (com foco em plantas herbáceas, arbustivas e trepadeiras) e "Plantas e biomas" (entendendo a vegetação ao um contexto ambiental mais amplo). Participaram das atividades estudantes do $1^{\circ}$ ao $4^{\circ}$ ano, que entre 2015 e 2017 cursaram as disciplinas "Desenho artístico", "Teoria e História do Paisagismo" e "Arquitetura da Paisagem I, II e III".

O principal recurso utilizado foi o desenho de observação ${ }^{5}$ - realizado, portanto, in loco, nas ruas da cidade, em praças e jardins públicos como o Jardim Botânico de São Paulo, na própria escola e inclusive em espaços privados. O desenho mostrou-se como ferramenta privilegiada para um olhar ativo - envolvendo, em uma mesma ação, processos de análise (da ecologia, da morfologia, da espacialidade e volumetria das plantas observadas) e síntese (característica fundamental do desenho de observação, entendido não como reprodução da realidade - para a qual a fotografia parece ser um recurso mais adequado). Nesse sentido, a conceituação proposta por Paul Valéry foi fundamental:

5 Complementarmente às atividades de desenho - para as quais, além de Valéry, as obras de Munari (2014) e Hutchinson (2012) foram referenciais importantes -, foi consultada também bibliografia especializada das áreas de botânica e arborização, desenho urbano e arquitetura da paisagem. No primeiro caso, destacam-se os livros de Lorenzi; já o desenho urbano e a arquitetura da paisagem, entendidos como campos inter-relacionados, foram estudados priorizando-se os conceitos, projetos e estratégias da Infraestrutura Verde, apresentados e discutidos em obras como a de Herzog (2013). O estudo de projetos referência, os quais mencionaremos mais adiante, também foi um recurso importante dos exercícios.
Há uma imensa diferença entre ver uma coisa sem o lápis na mão e vê-la desenhando-a. Ou melhor, são duas coisas muito diferentes que vemos. Até mesmo o objeto mais familiar a nossos olhos torna-se completamente diferente se procurarmos desenhá-lo: percebemos que o ignorávamos, que nunca o tínhamos visto realmente (...). O desenho de observação de um objeto confere ao olho certo comando alimentado por nossa vontade. Neste caso, deve-se querer para ver e essa visão deliberada tem o desenho como fim e como meio simultaneamente (VALÉRY, 2012, p. 61 - Grifos do autor).

Assim, desenhar foi um caminho não apenas para a obtenção de informações sobre as plantas, como também para o desenvolvimento de um pensamento crítico sobre elas, no sentido de possibilitar que fossem feitas relações e levantados questionamentos a partir dessas informações. Possibilitou, ainda, um maior envolvimento e uma sensibilização em relação ao verde, como veremos.

\section{Resultados}

\section{"As Árvores e a cidade"}

Em "As árvores e a cidade", a proposição foi a de buscar árvores e palmeiras nativas na região metropolitana de São Paulo, escoIhendo algumas para desenhar in loco e observando suas características morfológicas (identificação das partes da planta: troncos ou estipes, folhas, flores, frutos, sementes); espaciais-ambientais (a sua estrutura, como ela se situa no espaço a seu redor e em relação à escala humana); e plásticas (cores, texturas, efeitos de sombra e luz).

Observando-se a produção dos estudantes, pode-se perceber como tais características foram apreendidas, na observação de cada espécie individualmente, e na comparação entre diferentes espécies. Por exemplo, a pequena eugênia (Eugenia sprengelii), que pelas suas dimensões reduzidas e folhagem delicada, adequada para topiarias, é uma espécie muito usada em pequenos jardins 
(Figura 2); o pau-jacaré (Piptadenia gonoacantha), cuja forma "desestruturada" ou "desorganizada" faz com que a espécie seja pouco utilizada em jardins de ênfase ornamental, mas extremamente importante ecologicamente, por ser uma espécie pioneira com crescimento acelerado, utilizada na recomposição de áreas degradadas (Figura 3); a gigantesca araucária (Araucaria angustifolia), o único pinheiro nativo do Brasil e em risco de extinção, cuja volumetria em forma de candelabro é destacada no desenho. Entenderam porque o pau-formiga (Triplaris americana) é uma espécie tão utilizada na arborização urbana de São Paulo: não somente pela floração vermelha e vistosa, entre agosto e outubro - aspecto claramente ressaltado no desenho - como por sua volumetria colunar e vertical, adequada a vias e calçadas mais estreitas, como frequentemente é o caso em São Paulo.
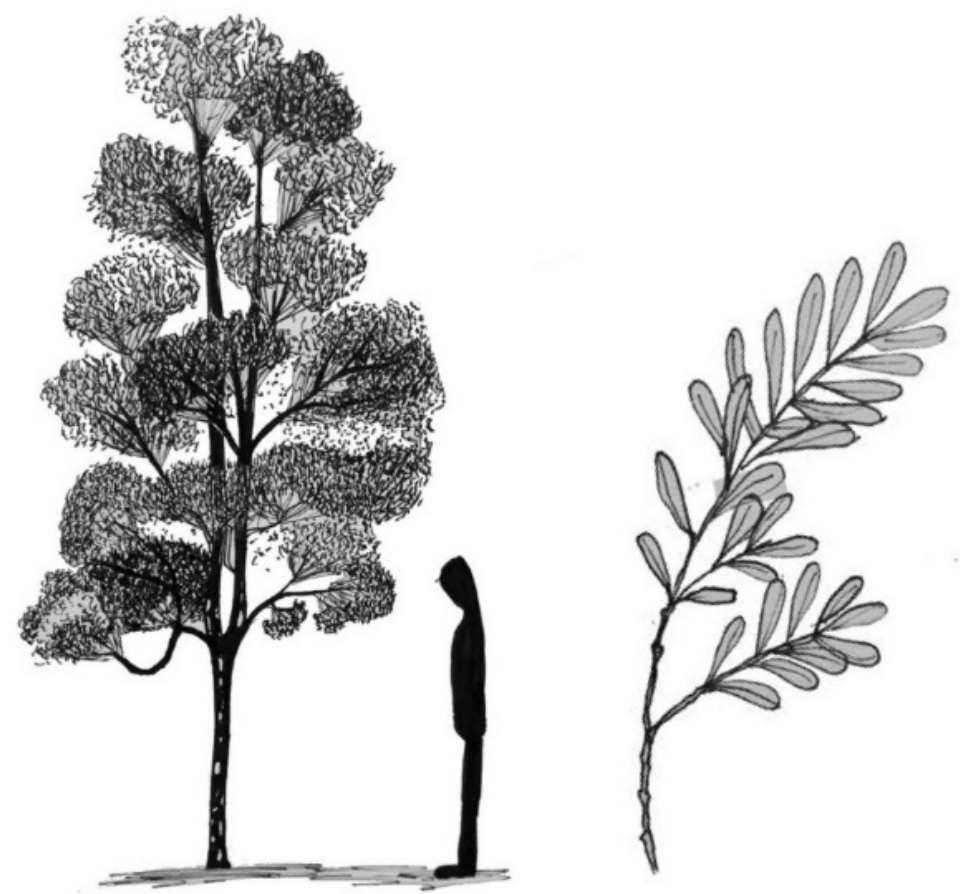

Figura 2 - Eugênia (Eugenia sprengelii) por Bruna Oliveira.

Fonte: A autora.

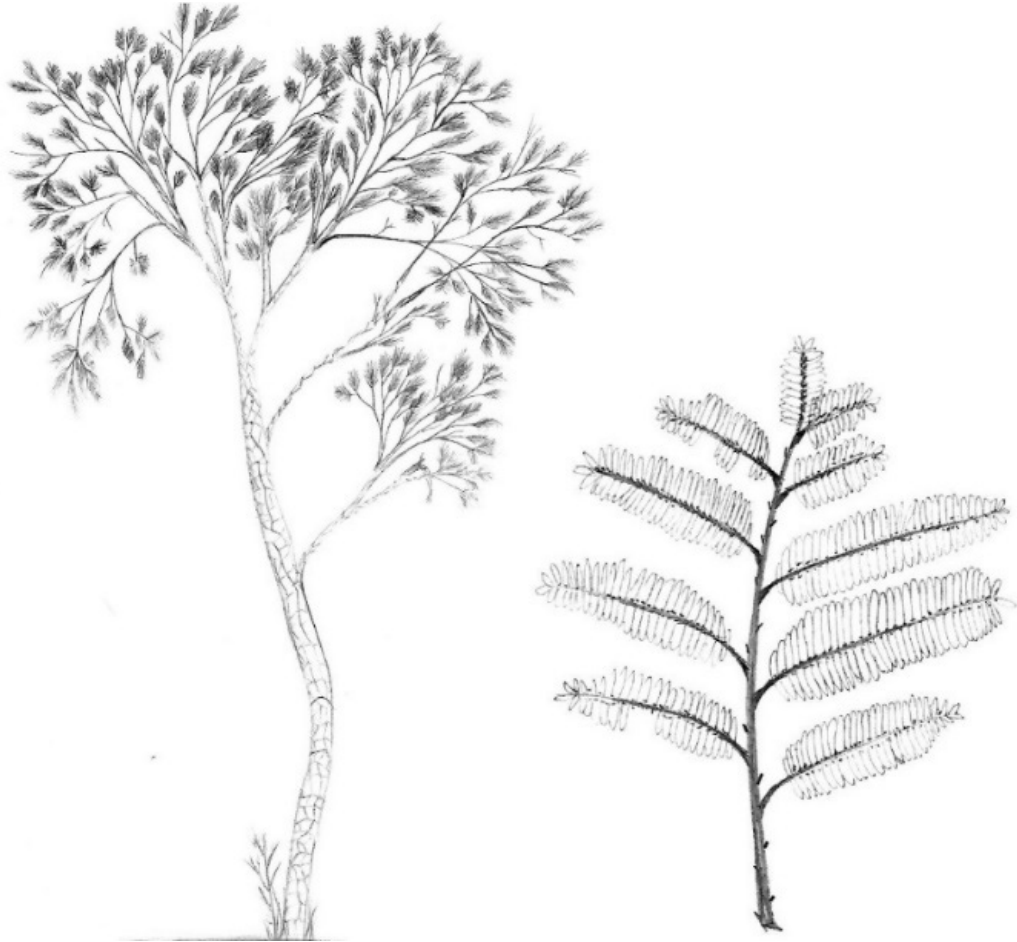

Figura 3 - Pau-jacaré (Piptadenia gonoacantha) por Guilherme Cajaíba. Fonte: A autora.

Depois de realizados os desenhos (cada um deveria estudar 5 árvores e 3 palmeiras nativas), foi preenchida uma ficha - na qual foram incluídos os desenhos, fotografias de frutos, flores e sementes, além de informações pesquisadas em manuais de identificação, como nome popular, nome científico, porte, diâmetro e formato da copa, interesse paisagístico da espécie (Figura 4).

Finalmente - considerando a qualidade dos trabalhos apresentados - foi proposto aos estudantes que as fichas fossem reunidas em duas publicações, para serem usadas como consulta em futuros 

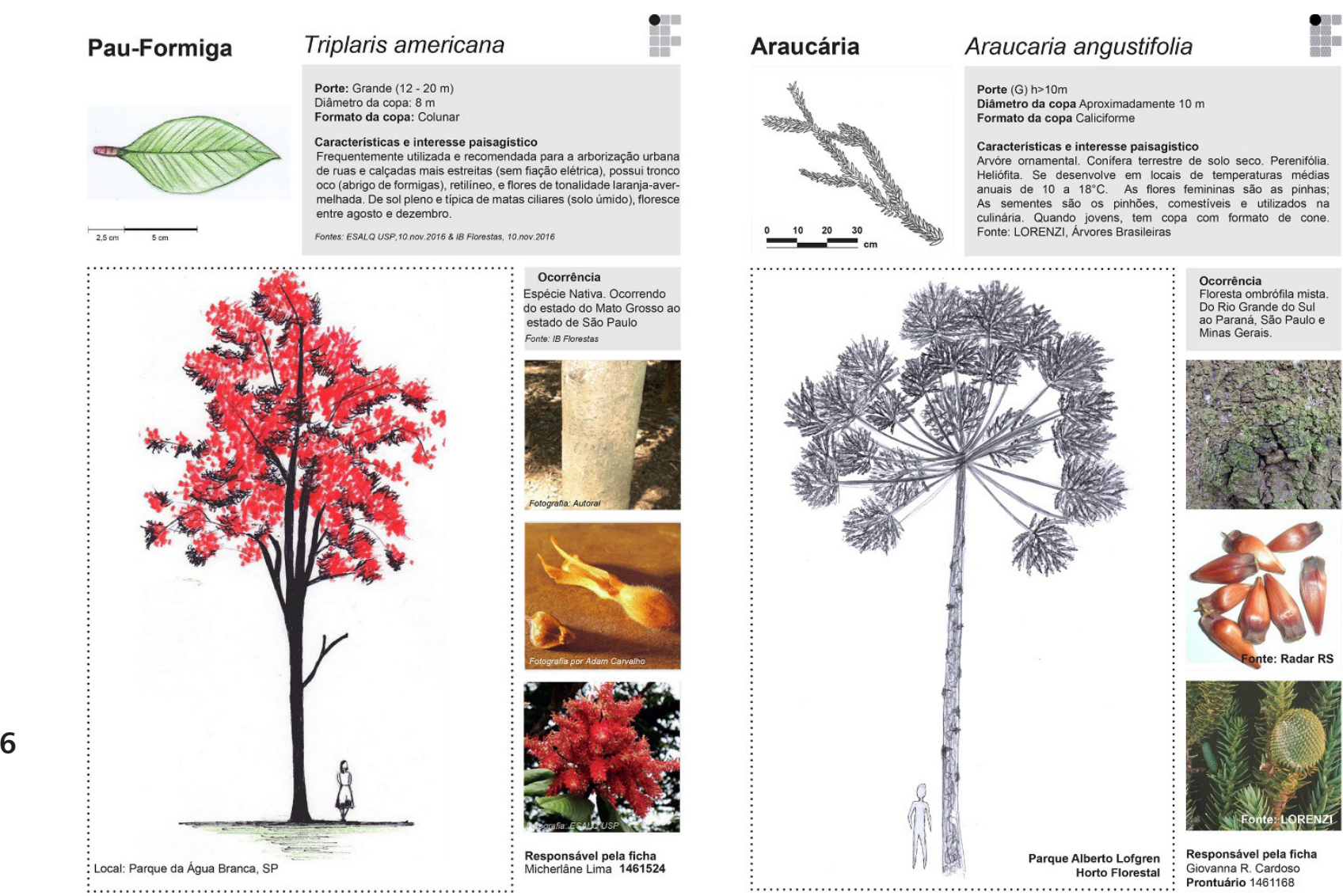

Figura 4 - Fichas de vegetação,

por Micherlâne Lima

Giovana Cardoso.

Fonte: A autora.

exercícios de paisagismo; a meta seria incluir no Livro das árvores e no Livro das palmeiras a maior diversidade possível, portanto, a turma precisou se organizar para levantar coletivamente um conjunto variado de espécies. A proposta foi aceita com entusiasmo; o design e organização dos dois volumes ficou a cargo dos próprios alunos (Figura 5).

Alguns aspectos dessa experiência devem ser destacados aqui. 0 primeiro deles é que o desafio da observação in loco explicitou o fato de que cada espécie vegetal é diferente, do ponto de vista formal, espacial e morfológico. À primeira vista, para alguém familiarizado com o assunto, essa pode parecer uma conclusão óbvia; mas, como notou uma aluna, essa não é a visão que prevalece: "O exercício nos ajudou a superar o senso-comum de que todas

as árvores são iguais". Além disso, o trabalho de escolha das fichas para os livros fez com que fosse necessário comparar os vários desenhos de uma mesma espécie, feitos por pessoas diferentes demonstrando como cada espécie é constituída por indivíduos de aspectos diversos; e também como a percepção desses aspectos pode variar de acordo com o desenhista (Figura 6$)^{6}$ - fatores que

\footnotetext{
6 No Livro das árvores, que reúne desenhos feitos por professores Ticuna (o mais numeroso povo indígena da Amazônia brasileira), pode-se notar como uma mesma espécie - a palmeira buriti (Mauritia flexuosa), por exemplo - ganha inúmeras representações: por vezes, repletos de frutos, ou ainda, os animais que os consomem e as figuras dos guardiões das árvores e da floresta (GRUBER, 1997; CANÇADO, 2017). É uma abordagem completamente diversa daquela da tradição científica ocidental, que em geral entendeu o desenho, em sua relação com a botânica, como um recurso meramente técnico - do qual são excluídos os aspectos culturais e subjetivos ligados à percepção da flora.
} 

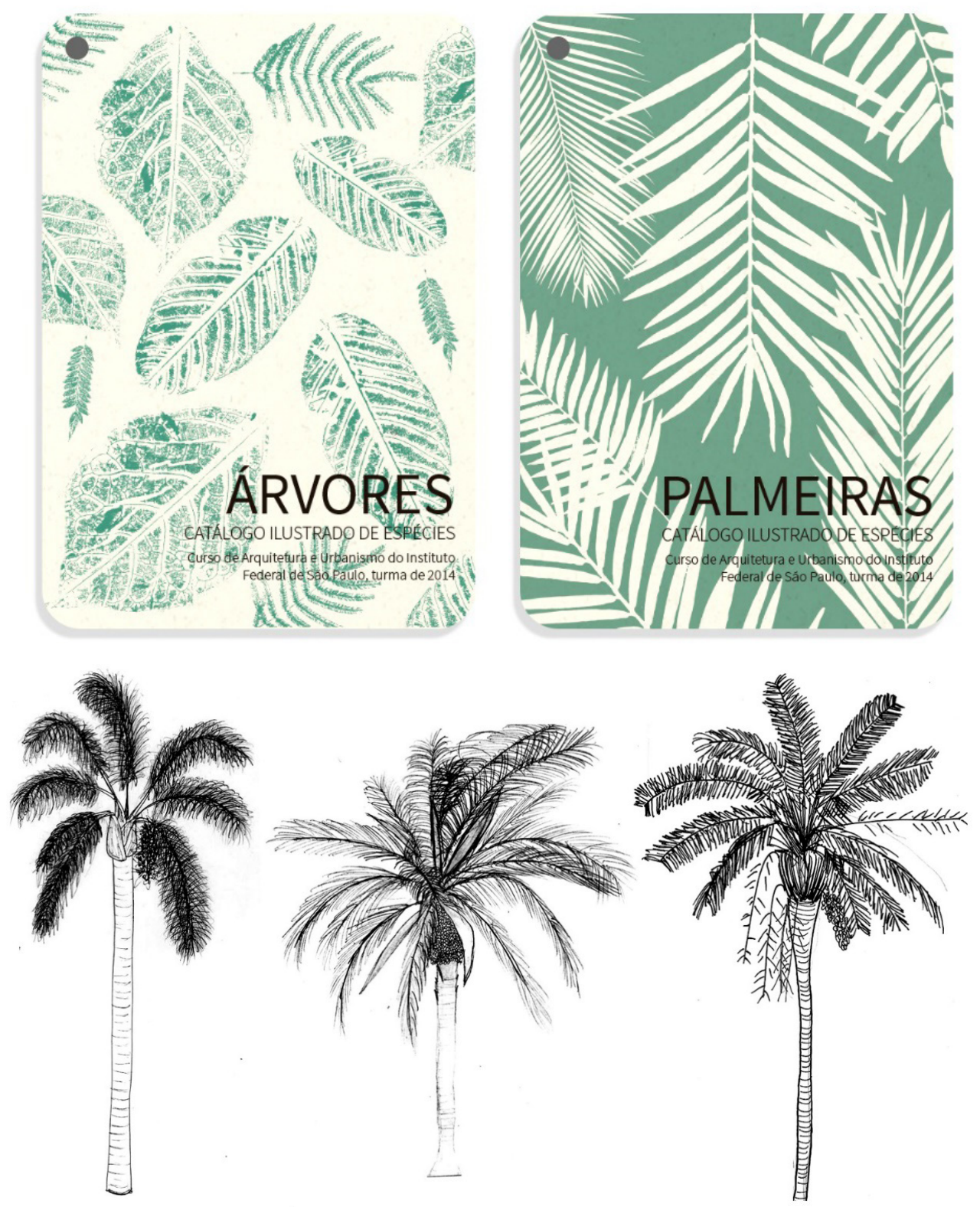

Figura 5 - Capas dos livros organizados pelos alunos, projeto gráfico de Camilla Freitas Bruna Oliveira.

Fonte: A autora, Camilla Freitas e

Bruna Oliveira.

Figura 6 - Jerivá (Syagrus romanzoffiana), por Bianca Neuman, Julia Ananias e Raquel Maris. Fonte: A autora. 
certamente se contrapõem à homogeneização preponderante na Cegueira Vegetal.

Um segundo aspecto relevante, decorrente do primeiro, é que o trabalho de busca e observação de exemplares na cidade fez com que se pudesse reconhecer a grande diversidade de espécies de árvores e palmeiras existentes. O estudo das palmeiras, particularmente, levou à percepção da "quantidade de espécies que nos rodeiam, em especial as espécies exóticas" (nas palavras de um aluno); apesar da imensa diversidade das Arecaeae brasileiras - segundo a Embrapa, mais de 250 espécies (BROCHADO, 2016) -, poucos estudantes conseguiram achar exemplares da flora nacional plantados no espaço urbano, tendo que recorrer ao Jardim Botânico para encontrá-los.

Por fim, a questão da desvalorização das espécies nativas e da predominância de exóticas explicitou, como, no Brasil, são raros os projetos urbanísticos e paisagísticos nos quais a arborização é elemento de destaque, e mais raros ainda aqueles que pensam as árvores como elementos da Infraestrutura Verde e partes de sistemas mais complexos. Assim, em paralelo ao estudo das árvores e palmeiras, foram levantados projetos-referência de streetscapes, corredores verdes e florestas urbanas, a maioria deles implantados fora do Brasil - que puderam então ser lidos a partir de um ponto de vista crítico e situados em relação ao contexto brasileiro? ${ }^{7}$.

\section{"Plantas no jardim"}

Aqui, as plantas ornamentais constituíram o objeto de estudo, em especial as herbáceas, as arbustivas e as trepadeiras. Dentre as atividades realizadas, foi feita uma visita ao Jardim Botânico de

\footnotetext{
7 Parte desses projetos foi apresentada aos alunos pela professora, mas os estudantes também foram estimulados a pesquisar referências de seu interesse em sites especializados como o Landezine (http://landezine.com/). Foi priorizado o estudo de projetos nos quais a vegetação teve um papel de elemento estruturador do espaço, além de cumprir funções ecológicas, estéticas e educativas; as experiências paisagísticas e de desenho urbano nas cidades colom estéticas e educativas; as experiências paisagísticas e de desenho urbano nas cidades colomRio Medellín, projetos mais pontuais de espaços públicos no entorno de escolas, bibliotecas e outros equipamentos urbanos, além da requalificação dos cerros e humedales, são bons exemplos de referências discutidas.
}

São Paulo ${ }^{8}$ para observar as plantas; e o projeto, planejamento e implantação de um pequeno jardim na própria escola - algo que a maioria dos estudantes nunca havia feito, que envolveu conhecimentos teóricos e práticos e um grande comprometimento por parte dos estudantes para a sua concretização.

"Plantas no jardim" partiu do princípio de que o ato de plantar é fundamental para o paisagista. Propôs, portanto, o contato dos estudantes com aspectos práticos inerentes ao projeto, a começar pelo conhecimento da própria vegetação. Para isso, a proposta foi a de desenhar a grafite, carvão ou nanquim as plantas da estufa tropical do Jardim Botânico (Figura 7), e em seguida, a paisagem junto ao grande lago existente no jardim. Os trabalhos revelam olhares atentos, que captam a estrutura, a forma e a morfologia das plantas maiores ou mais exuberantes - a exemplo das helicônias, samambaias e bromélias - e a delicadeza de musgos e outras plantas diminutas que, sem o desafio do desenho de observação, passariam despercebidas. Captam também a complexidade e a riqueza dos conjuntos formados por espécies variadas, pedras e água (Figuras 8 e 9).

Já os desenhos realizados na parte externa do jardim expressam como, em uma visada mais ampla, a planta individual transmutase em componente fundamental de um todo maior, que convencionou-se chamar de paisagem; herbáceas, arbustivas e trepadeiras, além é claro das árvores e palmeiras, podem então ser lidas como uma infinidade de linhas, massas, manchas, texturas um importante aprendizado espacial e projetual para o paisagista, que deve saber transitar entre escalas (Figuras 10 e 11).

A proposição da implantação de um jardim - envolvendo a turma inteira, em um processo que incluiu o projeto paisagístico (Figura 12), os projetos de drenagem e irrigação, o planejamento financeiro e de obras, a arrecadação de recursos e, finalmente, a execução em mutirão - pode ser encarada como um aprofundamento desse primeiro exercício.

8 O Jardim Botânico de São Paulo, fundado em 1938, é uma grande área com remanescentes de Mata Atlântica situada dentro do Parque Estadual das Fontes do Ipiranga. Conta com um riacho renaturalizado, cachoeiras e lagos, um museu botânico e estufas de plantas tropicais, oferecendo muitas possibilidades para a realização de atividades de ensino. 

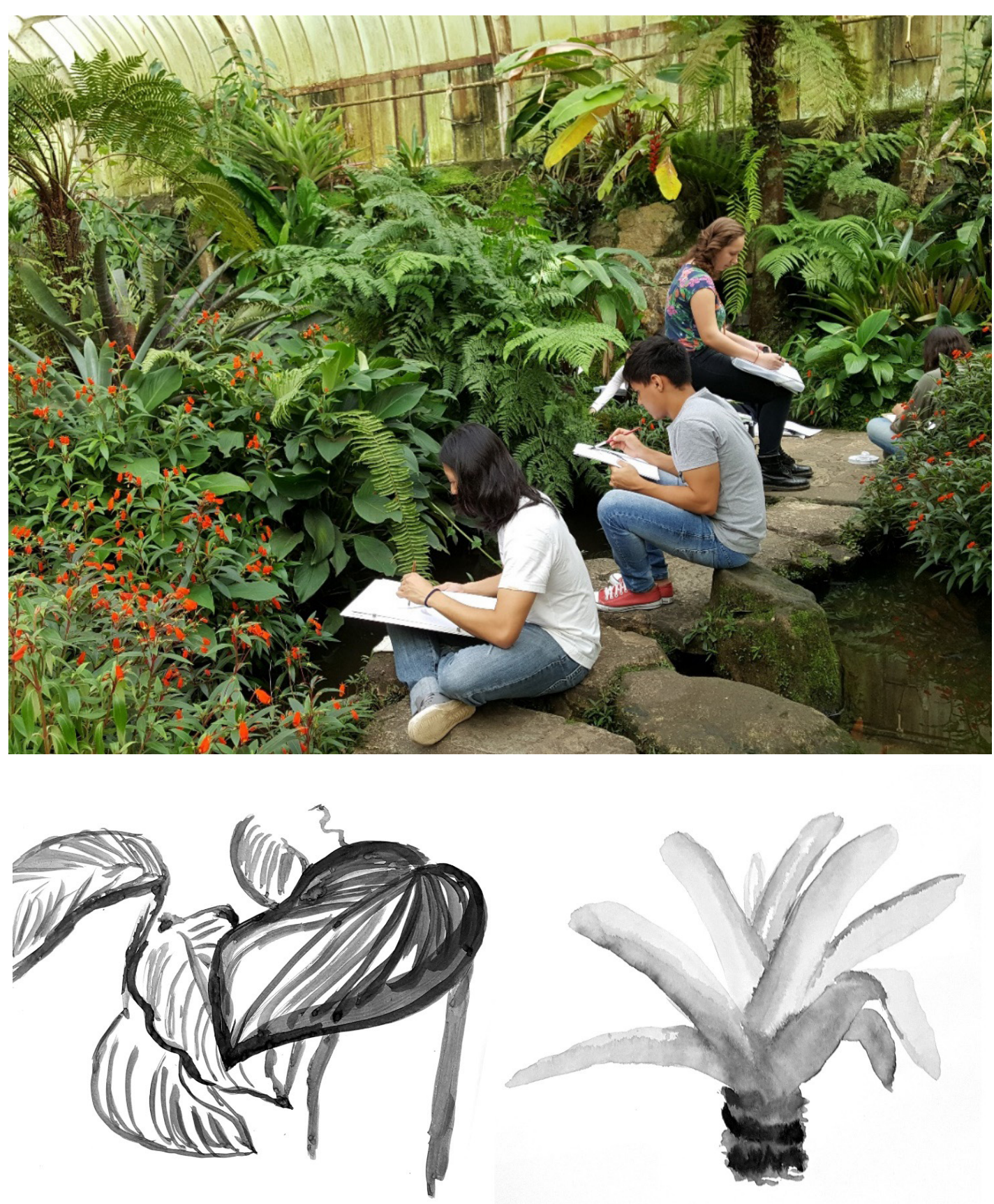

Figura 7 - Desenhando na estufa de plantas tropicais do Jardim Botânico de São Paulo. Fonte: A autora.

Figura 8 - Espécies da estufa de plantas tropicais, por William Assis e Laura Scomparim. Fonte: A autora. 

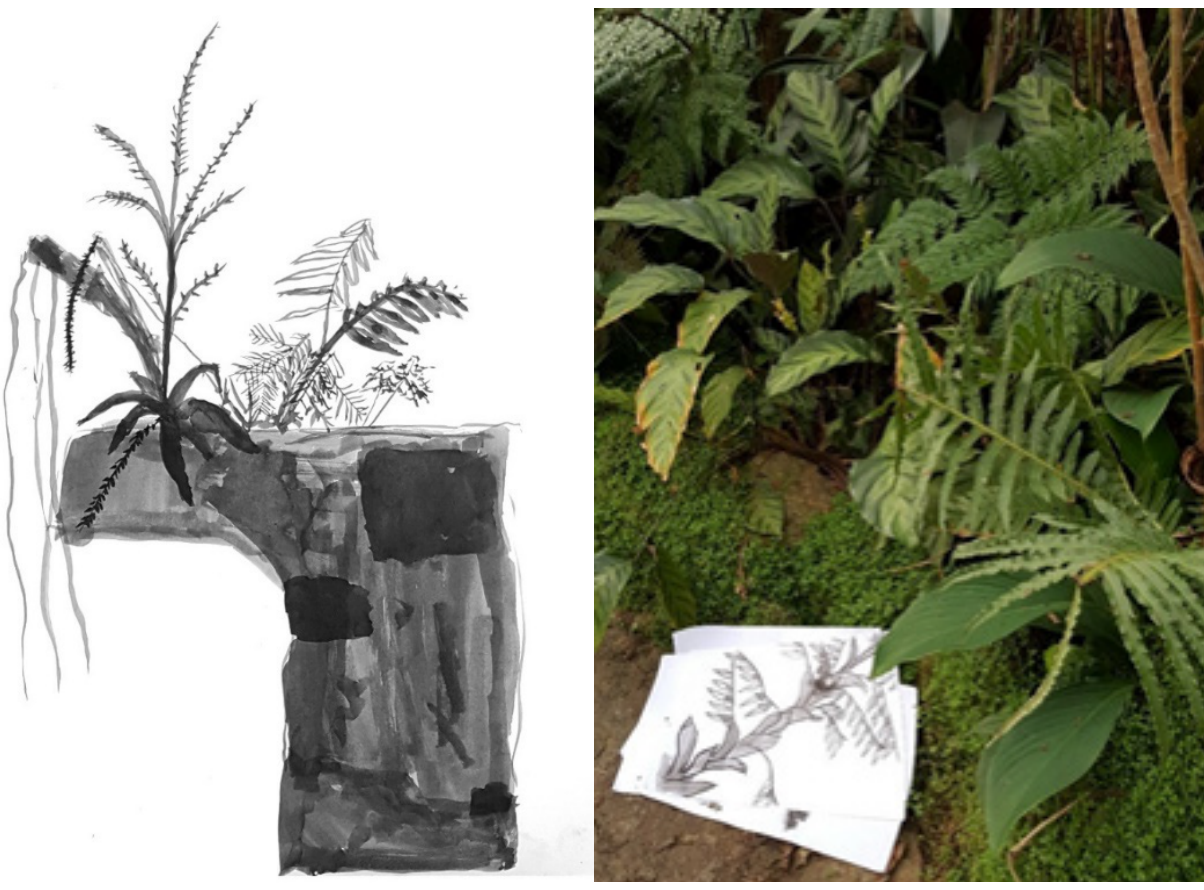

10

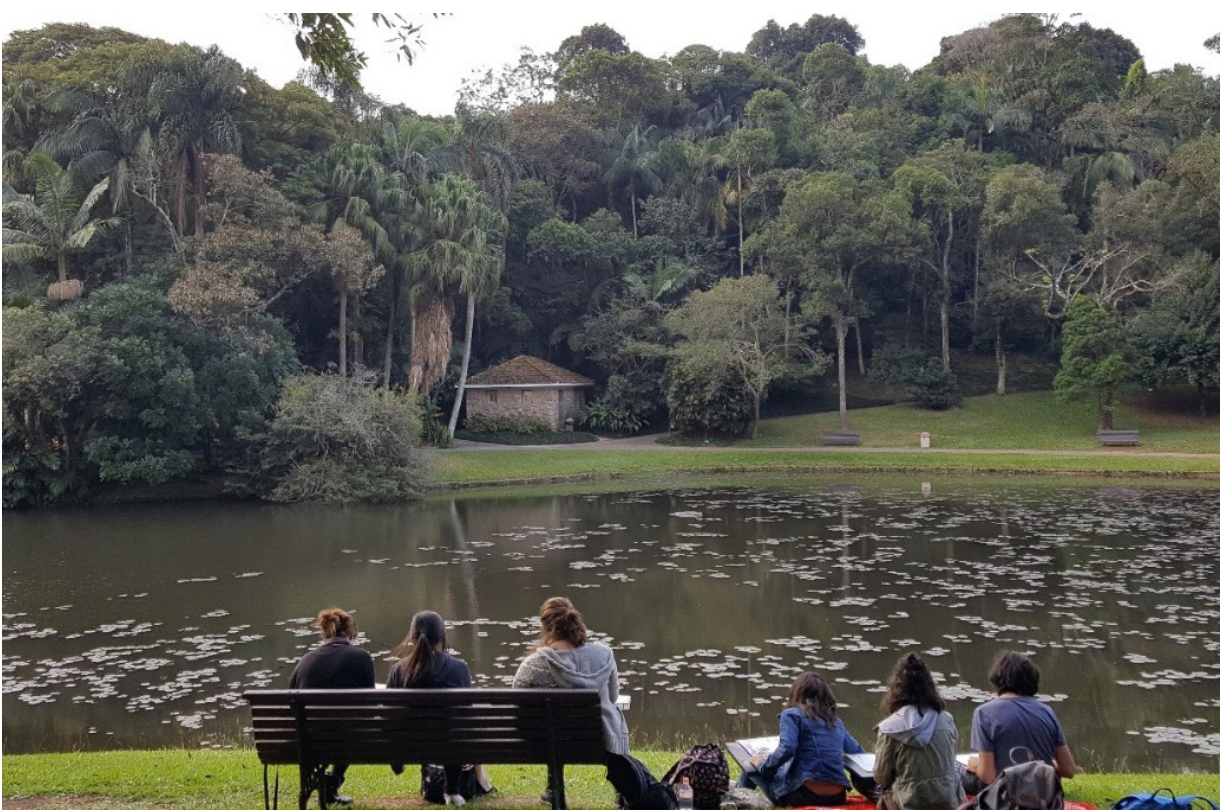

Figura 10 - Desenhando junto ao lago no Jardim Botânico de São Paulo.

Fonte: A autora.

Figura 9 - Espécies da estufa de plantas tropicais, por Bruno Franco da Cruz e Katia Wu.

Fonte: A autora.

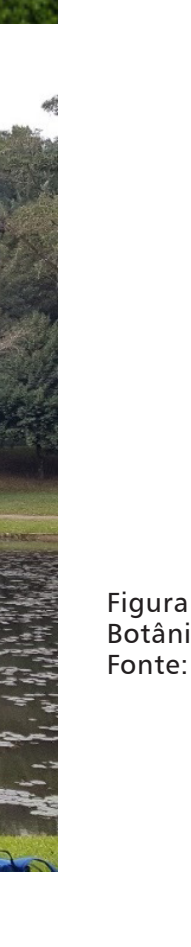

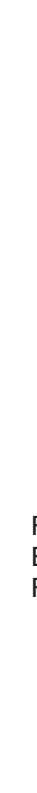




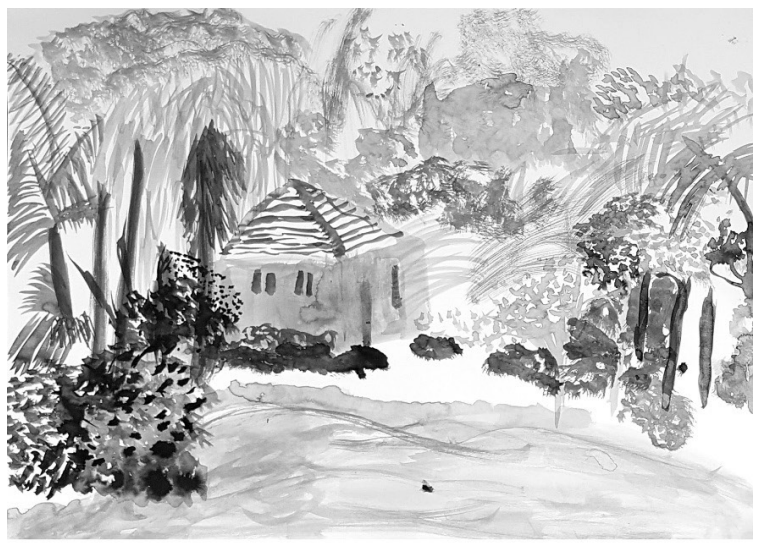

$\Rightarrow$ 罂 *2

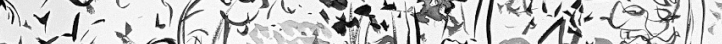

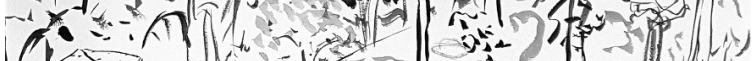

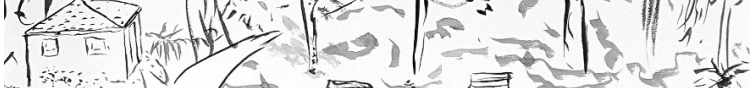
正

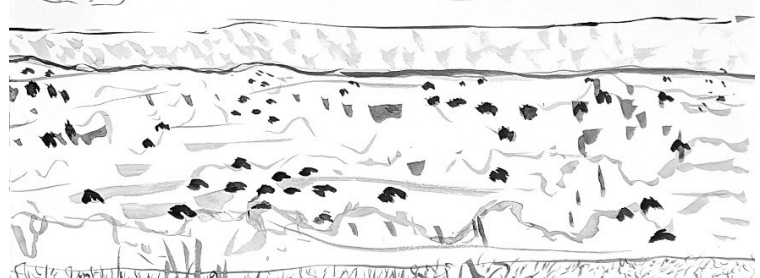

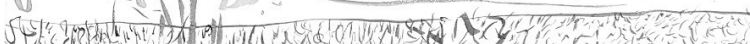

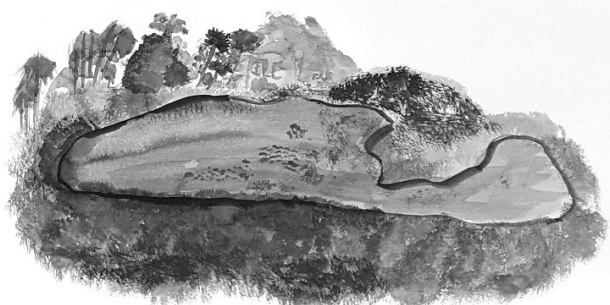

Figura 11 - Paisagem e vegetação junto ao lago, por Juliana Santana, Gabriel Leda e Nicolas Floriano. Fonte: A autora.

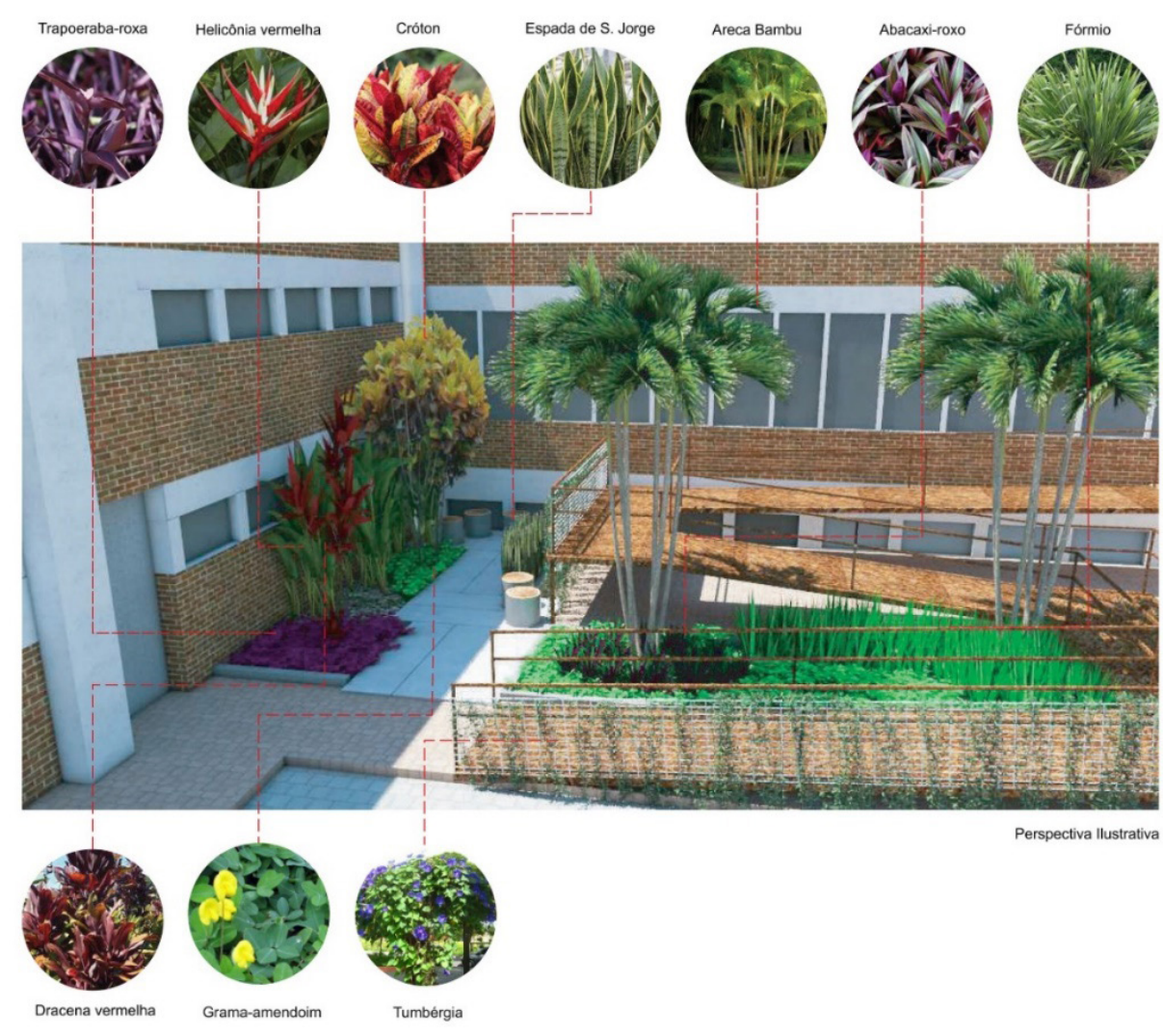

Figura 12 - Projeto do jardim, perspectiva ilustrativa, por Bruna Oliveira, Camilla Freitas, Erika Mayumi, Gabriela Tiemi, Giovana Cardoso e Vinicius Gonzales.

Fonte: A autora. 
Embora tenham sido colocadas algumas restrições ao projeto - como a área, que devia ser de poucos metros quadrados, e a limitação no uso elementos de maior complexidade construtiva, como pisos e mobiliário - em relação à vegetação, o trabalho permitiu explorar diversas questões. Entre elas, a especificação vegetal, estimulando os alunos a pesquisar as exigências de água, solo e luz de cada planta e a sua adequação ao espaço existente, e a buscar plantas disponíveis comercialmente e financeiramente acessíveis (levando-os a perceber como, mesmo em uma grande cidade como São Paulo, é relativamente pequena a diversidade de nativas comercializadas); as múltiplas possibilidades de composição paisagística, a partir das características de cada planta e das relações entre espécies - percebendo as diferenças entre o plantio em massas ou em linhas, regular ou orgânico, e as possíveis combinações de cores, formas, texturas e alturas; e a prática de plantio, ou seja, os cuidados e ações necessários ao sucesso do jardim, tais como a preparação das mudas e touceiras, os cuidados ao plantá-las, a adubação: um conhecimento elementar mas que poucos estudantes haviam experimentado na prática.

Os projetos de irrigação e drenagem, por sua vez, expuseram as condicionantes técnicas que viabilizam a vegetação em um jardim, e que muitas vezes são negligenciadas por paisagistas e arquitetos. Por fim, pode-se afirmar que a construção coletiva do espaço - da elaboração dos projetos à limpeza do terreno e preparo do solo, dos elementos construtivos ao plantio e à primeira rega, das planilhas
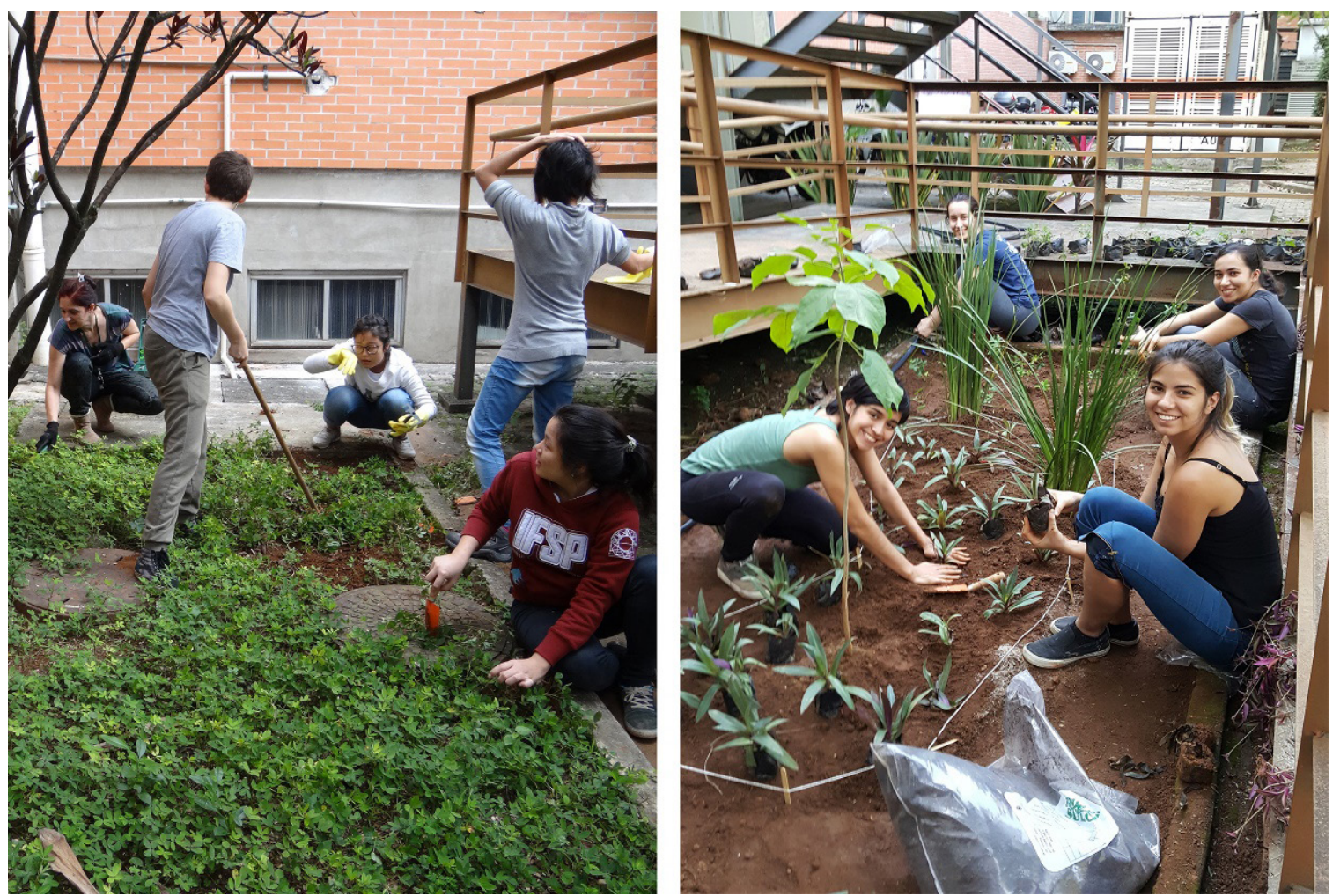

Figura 13 - Implantação do jardim em mutirão. Fonte: A autora. 
orçamentárias e cronograma de trabalho à arrecadação de fundos - foi uma forma efetiva e afetiva de aproximar os estudantes da prática paisagística, exigindo de cada um cuidado, envolvimento e comprometimento para que a experiência tivesse sucesso (Figura 13). E de fato, o jardim logo foi apropriado não apenas por seus construtores, mas também por estudantes de outras turmas e cursos, como área aberta de descanso nos intervalos entre as aulas.

\section{"Plantas e biomas"}

Expandindo os horizontes do "ver o verde", o entendimento da vegetação em seu contexto - em suas relações com outros seres vivos e com o meio - foi a inspiração desse exercício. Aqui, os estudantes tiveram como desafio pesquisar e visitar remanescentes de biomas na Região Metropolitana de São Paulo, e as dinâmicas das diversas formações ali presentes, como campos, alagados, matas de galeria - descobrindo por conta própria lugares que eles (e a maioria dos paulistanos) nem imaginavam existir: grandes áreas como o Parque Estadual do Juqueri, por exemplo, último remanescente do Cerrado na Grande São Paulo; ou o pequeno jardim de brejo criado com fins educativos no Jardim Botânico, trazendo à tona a revalorização dos alagados - que parte da população vê com maus olhos, utilizando-os como depósitos de lixo, e que o mercado imobiliário cobiça enquanto áreas para construção, aterrando-os na primeira oportunidade. Houve ainda estudos sobre as várias fitofisionomias da Mata Atlântica (que,

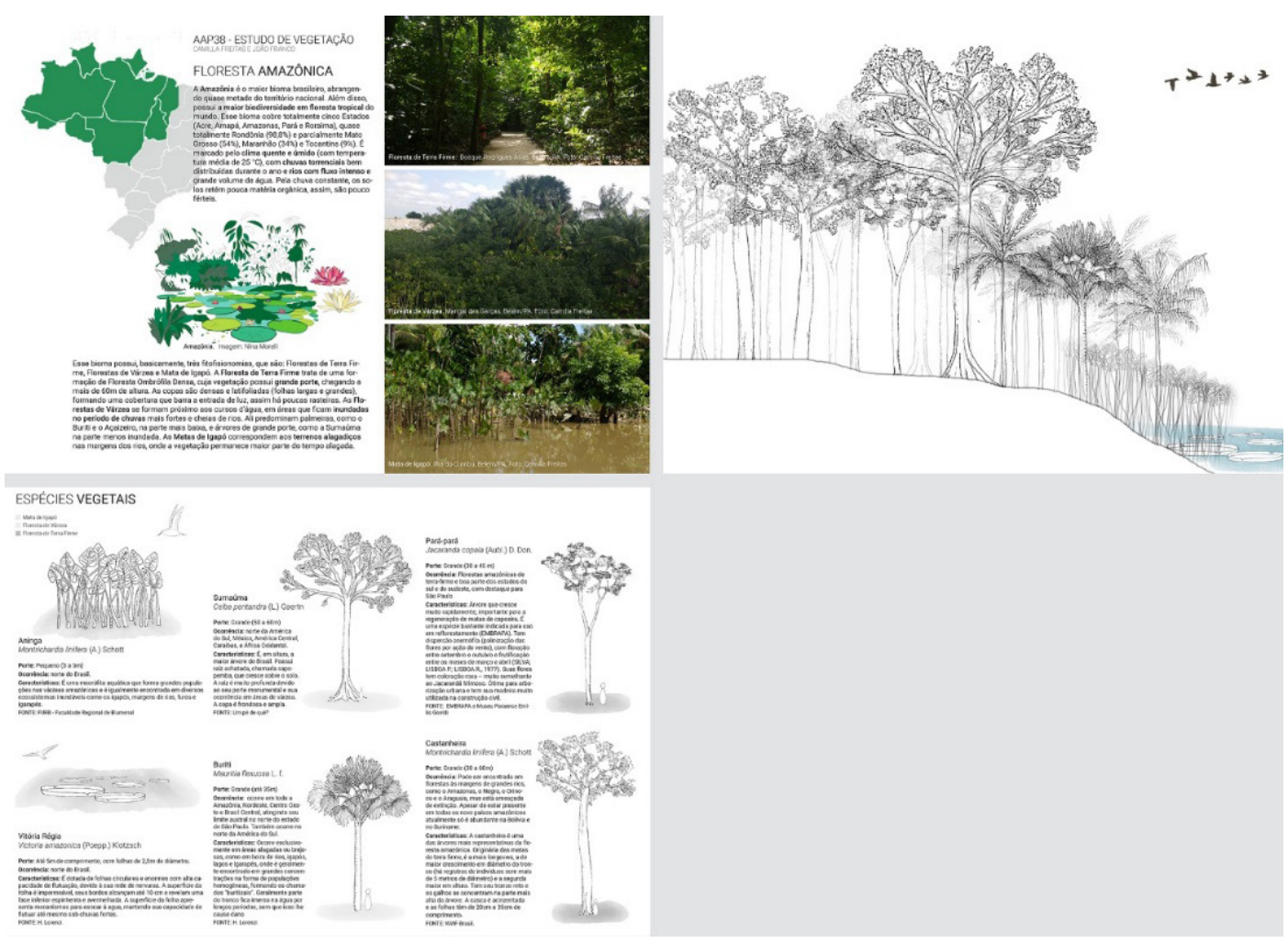

Figura 14 - Pranchas de "Plantas e biomas: Amazônia", por Camilla Freitas e João Franco. Fonte: A autora. 
junto com os campos do Cerrado, foi um dia o principal bioma da região da capital paulista), e mesmo um estudo sobre a Amazônia, já que uma das alunas teve a oportunidade de viajar para o Norte do país (Figura 14)

Além das visitas, foram feitas pesquisas bibliográficas e uma palestra na qual um botânico conceituou e apresentou os biomas brasileiros - respondendo também às questões que surgiram no decorrer das pesquisas e colaborando para a superação da visão do bioma como um conceito abstrato, separado do cotidiano dos habitantes das cidades. Os produtos finais da atividade foram pranchas reunindo informações sobre o bioma ou fitofisionomia (distribuição geográfica, clima), desenhos de algumas plantas observadas na visita e depois devidamente identificadas e, finalmente, um desenho geral, mostrando a complexidade ambiental, espacial e plástica do contexto em que as espécies foram encontradas.

Observando-se a produção dos alunos, pode-se ver como foram percebidas as relações entre a vegetação e o meio ambiente. Por exemplo, no estudo sobre a Amazônia, são apresentadas as principais características do bioma (sua grande biodiversidade o clima quente e úmido e a presença de grandes rios) e identificadas suas principais fitofisionomias. Enquanto as fotografias demonstram como essas formações estão presentes no Norte do Brasil - inclusive no contexto urbano, aparecendo em importantes espaços verdes públicos de Belém do Pará -, os desenhos revelam um interesse especial pela grande diversidade de palmeiras da região e pelas grandes árvores da floresta, como a sumaúma (Ceiba pentandra) e a castanheira (Bertholletia excelsa); eles também conseguem captar a notável relação que as espécies amazônicas estabelecem com a água e o regime de cheias dos rios. Destacam-se ainda, nos desenhos, plantas nativas bastante comuns e até desprezadas por parte da população - como a aninga (Montrichardia linifera), espécie de brejo cujo potencial como planta fitorremediadora vem sendo reconhecido recentemente (Figuras 15 e 16).

Os alunos que se voltaram para o entorno de São Paulo (Figuras 17,18 e 19), por sua vez, conseguiram demonstrar nos desenhos não apenas uma sensibilidade às possibilidades composicionais sugeridas pelos grupos de plantas espontaneamente estabelecidos - lição que tem sido aproveitada por muitos paisagistas nos chamados Jardins Naturalistas -, mas também sua percepção das características das zonas de transição entre áreas florestadas e desmatadas, nas quais ocorre o "efeito de borda". Também estiveram atentos às características das espécies, observando a coexistência de plantas invasoras amplamente difundidas (como o asiático curculigo, Curculigo capitulata) e espécies nativas, algumas delas em risco de extinção (como o samambaiaçu, Dicksonia sellowiana).

Em termos de vegetação, essa experiência pretendeu dar elementos para projetos paisagísticos nos quais - para além de estilos ou formalismos - o uso das plantas pressupõe relações: entre as espécies, entre a flora e a paisagem, a flora e a água, a flora e o solo, a flora e a fauna e, é claro, a flora e o as comunidades humanas. Contribuiu para ressaltar a importância de conceber e desenvolver o projeto dentro de uma visão ecológica, assim como na defesa humanista do jardim enquanto "associação entre plantas, solo, clima e gente" de Burle Marx (MOTTA, 1986, p. 10); no Jardim Planetário de Gilles Clément, sem cercas ou limites, em que os biomas são determinantes, e cujos cidadãos-jardineiros atuariam localmente e pensariam globalmente (OLIVEIRA, 2000); ou na Ecogênese de Fernando Chacel, a partir da qual se propõe a reinterpretação do ecossistema, recompondo-o por meio do replantio de espécies autóctones, em um trabalho multidisciplinar (CURADO, 2016) e que nunca deixa de ressaltar a importância do uso dos jardins pela população. As reflexões desses paisagistas, embora conhecidas no meio acadêmico e profissional, seguem desconhecidas pela maior parte da população brasileira, já que raramente são traduzidas em projetos e efetivamente materializadas no espaço das cidades.

A experiência trouxe ainda a possibilidade de reflexão sobre uma questão que, no exercício de construção do jardim, não pôde ser aprofundada: a dos projetos paisagísticos que se restringem ao uso de espécies comercialmente disponíveis, em sua maior parte exóticas - enquanto plantas nativas deixam de ser consideradas, seja pelo fato de não serem produzidas nos 


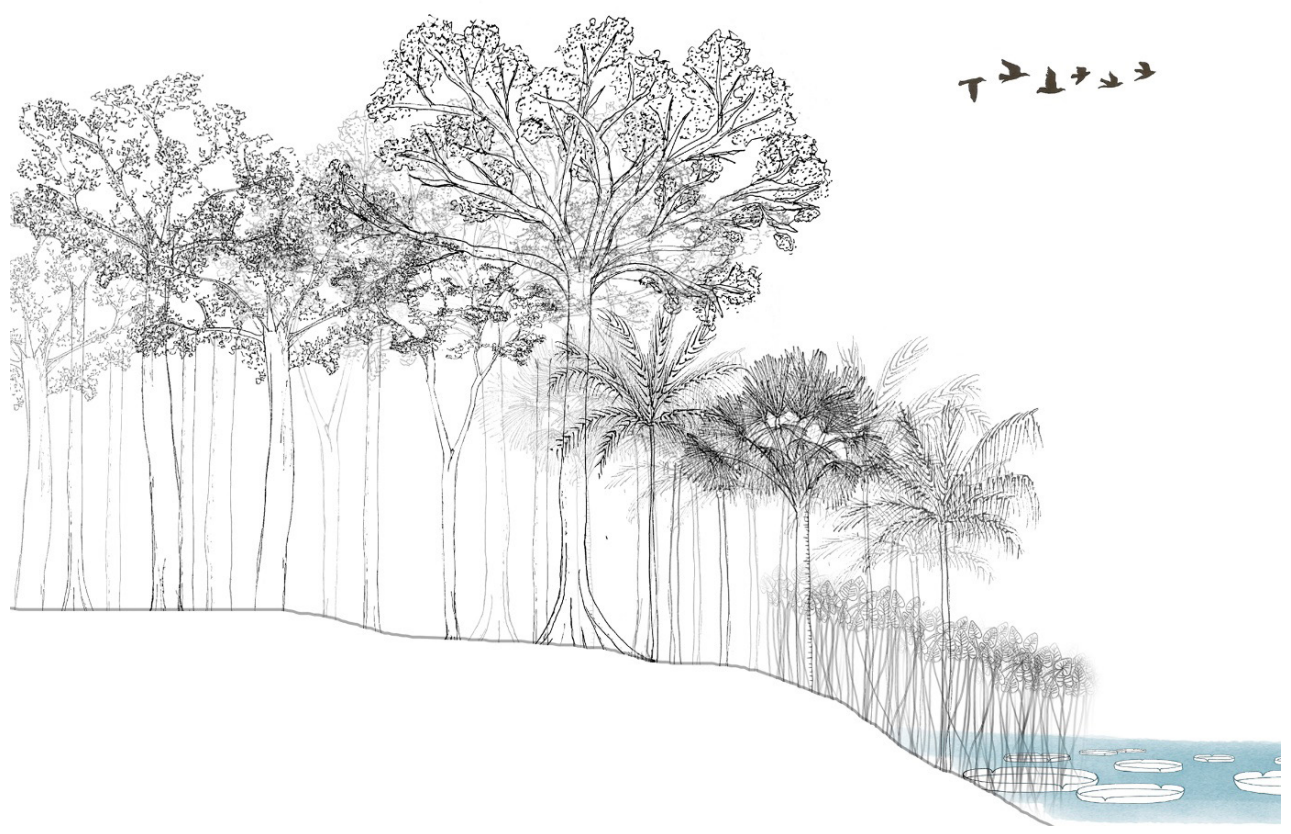

Figura 15 - "Plantas e biomas: Amazônia", por Camilla Freitas João Franco em Belém-PA.

Fonte: A autora.

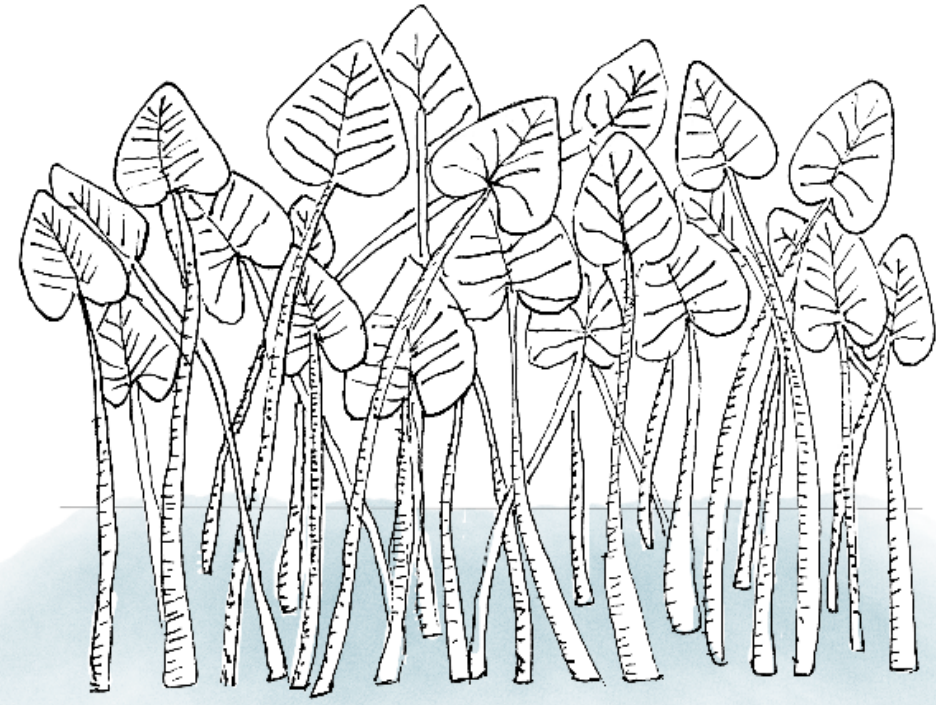

Figura 16 - Estudo de espécies:

aninga (Montrichardia linifera), por

Camilla Freitas e João Franco.

Fonte: A autora. 


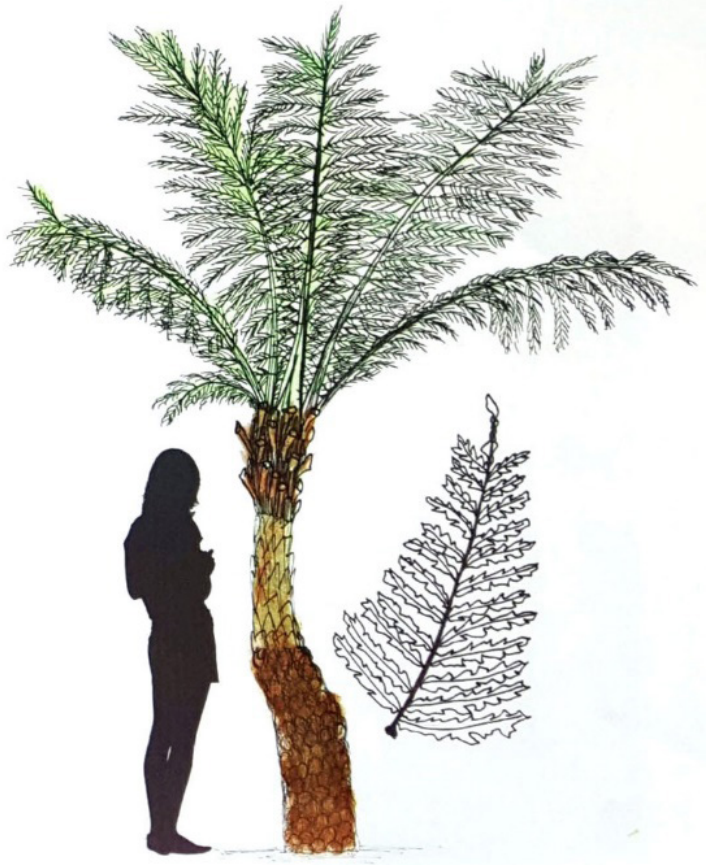

16

Figura 17 - Estudo de espécies: samambaiaçu (Dicksonia sellowiana), por Bruna Oliveira e

Vinícius Gonzales.

Fonte: A autora.

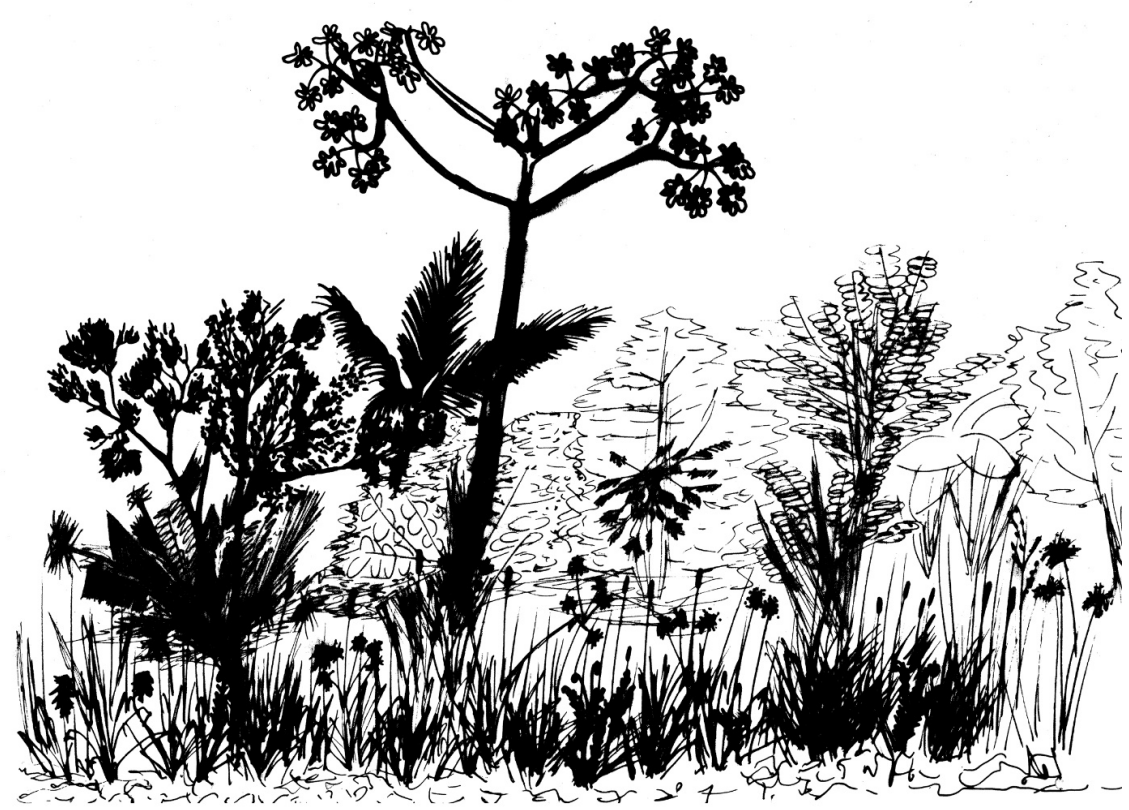

Figura 18 - Estudo "Plantas e biomas: Mata Atlântica", por Bruna Oliveira e Vinicius Gonzales no Parque Natural Municipal Nascentes de Paranapiacaba, Santo André-SP. Fonte: A autora.

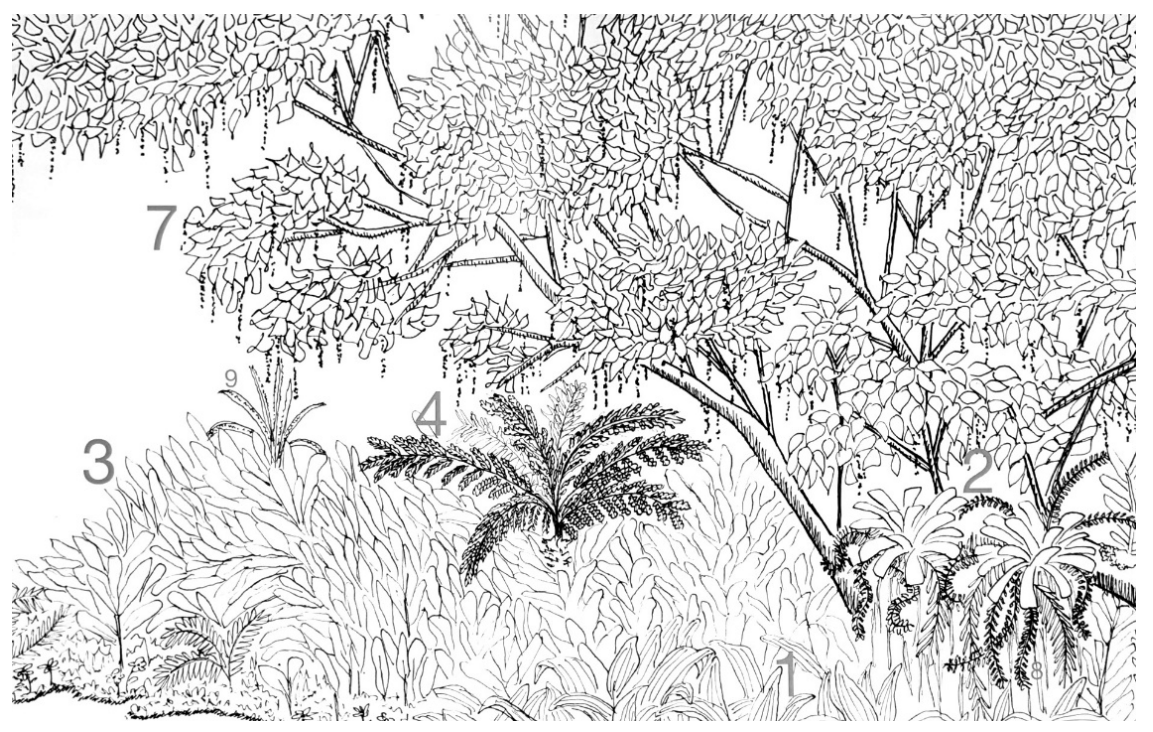

Figura 19 - Estudo "Plantas e biomas:

Cajaíba no Jardim Botânico, São Paulo-SP.

Fonte: A autora. 
viveiros locais, seja por serem vistas como selvagens ou daninhas. Nesse sentido, a atividade relaciona-se a algumas experiências artísticas que se delineiam atualmente, demonstrando uma mudança de mentalidade quanto às plantas antes desvalorizadas e aos ambientes onde elas crescem - e que o fazem a partir de recursos como o desenho e o projeto: por exemplo, os Jardins de Cerrado, nos quais a paisagista Mariana Siqueira mostra o valor e as possibilidades do uso de plantas nativas do cerrado para a constituição de jardins; o projeto Cerrado Infinito, em que o artista Daniel Caballero desenha a vegetação nativa do cerrado paulista e propõe ações de substituição da vegetação exótica pelas plantas autóctones que resistem em terrenos baldios e outros vazios urbanos, "em um processo de descolonização vegetal da paisagem" (CABALLERO, 2016); e o projeto Ervas sp, da artista Laura Lydia, que fez um mapeamento das plantas ruderais que crescem no Minhocão, desenhando-as e reproduzindo os desenhos ampliados em lambe-lambes, colados ao lado das plantas - criando assim um percurso botânico-afetivo pela grande estrutura rodoviarista de concreto.

\section{Considerações Finais}

Para se pensar e fazer paisagismo a partir de parâmetros inovadores - considerando as "soluções baseadas na natureza" da Infraestrutura Verde e o seu impacto urbanístico e social, assim como a "participação na paisagem", como temos proposto -, é preciso também pensar, entre outros fatores, na formação dos profissionais da área, transformando os processos e métodos do próprio ensino. No entanto, na maior parte dos cursos de arquitetura do Brasil, esse ensino se dá de forma desconectada da realidade; forma e conteúdo, teoria e prática, estão completamente separados; a ideia de experimentação raramente comparece; e os aspectos sensoriais, subjetivos e vivenciais geralmente não são considerados como formas válidas de conhecimento.

Assim, nossa intenção foi demonstrar como o estudo da vegetação oferece um amplo leque de possibilidades que nos aproximam dessa transformação almejada do ensino de paisagismo; sistematizado e aprimorado enquanto metodologia de ensino, ele poderia quem sabe ser replicado em outras escolas ${ }^{9}$, ao trazer aos alunos uma série de competências teóricas e práticas essenciais ao projeto, tais como:

- O conhecimento das características morfológicas da vegetação;

- O conhecimento das características plásticas e estéticas da vegetação;

- Um conhecimento mínimo sobre a taxonomia das espécies, desenvolvendo a capacidade de diferenciar as plantas entre si;

- O conhecimento acerca das relações espaciais que se estabelecem entre a vegetação e o espaço urbano, e entre a vegetação e a escala humana;

- O conhecimento das características ecológicas da vegetação, compreendendo-a em seu bioma, bem como parte de um todo complexo envolvendo "plantas, solo, clima e gente";

- A identificação do papel da vegetação em projetos paisagísticos de referência (desde obras de renomados paisagistas brasileiros até experiências em curso pelo mundo), e uma visão crítica em relação à atual situação do verde nas cidades brasileiras.

- O contato com obras de artistas que têm a vegetação como tema, abrindo a possibilidade de pensar a natureza de forma mais conceitual, a partir da arte e da cultura;

9 Para transformar as experiências iniciais aqui relatadas em uma metodologia de ensino propriamente dita, alguns caminhos poderiam ser cogitados, ao menos como ponto de partida, para as discussões entre docentes da área: por exemplo, incluir o estudo de vegetação como conteúdo nas disciplinas de projeto e de desenho já existentes nos cursos de Arquitetura e Urbanismo, preferencialmente entendendo-o como uma sequência a ser desenvolvida gradualmente, ao longo da formação dos alunos; estimular a participação de profissionais de outras áreas (biólogos, agrônomos, cientistas ambientais) nas disciplinas, tendo em vista a importância da interdisciplinaridade para o campo do paisagismo e paraum maior entendimento acerca das funções e possibilidades da vegetação; fomentar atividades de pesquisa
e extensão ligadas ao estudo da vegetação, ampliando o alcance do tema e buscando fazer com que ele se relacione mais ao cotidiano dos estudantes e da comunidade, valorizando a aprendizagem baseada no conhecimento dos próprios estudantes, no engajamento e na "participação na paisagem". 
- A observação e a vivência de espaços verdes urbanos até então desconhecidos ou desvalorizados, especialmente o Jardim Botânico e demais áreas de preservação ambiental da Região Metropolitana de São Paulo;

- O conhecimento prático e instrumental sobre a implementação de um projeto paisagístico, incluindo as exigências ligadas ao plantio e à manutenção da vegetação.

Para além do caráter prático-instrumental de tais competências, no entanto, parece-nos que o trabalho possui uma significação mais ampla. A partir dele, muitos estudantes descobriram que as plantas são seres importantes e interessantes, assumindo uma posição de engajamento - bastante clara no depoimento da aluna que, avaliando o processo de aprendizado, revelou sentir "uma paixão muito maior pela vegetação". Na ligação sensível e afetiva do sujeito com o objeto, nas ações de descoberta e (re) conhecimento da flora em suas várias dimensões, pode-se dizer que os estudantes começaram a de fato ver o verde. Com isso, não apenas enriqueceu-se a formação dos futuros paisagistas, mas também, mais amplamente, foi dado um pequeno passo na direção de uma mudança de mentalidades, de uma mudança social e cultural que, talvez um dia, permita-nos superar a ignorância da Cegueira Vegetal e a visão colonizada do verde como "cor do perigo".

\section{Agradecimentos}

Amanda Rovaron, Ana Luisa Ribeiro, Anderson Santos, Beatriz Tone, Bianca Neuman, Bruna Oliveira, Bruno Cruz, Camilla Freitas, Camila Sant'anna, Claudia Lavieri, Dayane Santos, Elaine Sales, Erika Harumi, Erika Mayumi, Erika Tempobono, Felipe Mujica, Franciny Marques, Gabriel Leda, Gabriela Russo, Gabriela Yokota, Giovana Cardoso, Guilherme Cajaíba, Isabelle Correia, João Franco, Julia Ananias, Julia Medeiros, Juliana Saft, Juliana Santana, Juliano Pita, Katia Wu, Laís Andrade, Laura Scomparim, Leticia Pádua, Ludmilla
Zuquetto, Mariana Kawaguti, Mariana Siqueira, Micherlâne Lima, Nicolas Floriano, Patrick Cantuária, Pedro Carmona Ribeiro, Pedro Leal, Raquel Maris, Renata Nunes, Simone Giovine/AFP, Tamires Kafka, Thais Kitzinger, Thais Tomita, Vinicius Gonzales, William Assis.

\section{ReferênCIAS Bibliográficas}

BROCHADO, Maria Luiza Costa. Palmeiras nativas do Brasil. Embrapa.br. Abril 2016. Disponível em <https://www.embrapa.br/busca-de-noticias/-/noticia/11266372/palmeirasnativas-do-brasil---livro-revela-os-potenciais-dessas-especies> Acesso em 20.9.2019

CABALLERO, Daniel. Guia de campo dos Campos de Piratininga. São Paulo, Editora do Autor, 2016.

CANCADO, Wellington. O que diriam as árvores? Piseagrama. Belo Horizonte, n. 11 2017, p. 118-125.

CURADO, Mirian M. de Campos. Paisagismo contemporâneo no Brasil: Fernando Chacel e o conceito de ecogênese. Docomomo. 2016. Disponível em <http://docomomo.org br/wp-content/uploads/2016/01/145.pdf > Acesso em 24.10.2019

DEAN, Warren. A ferro e fogo: a história da devastação da Mata Atlântica brasileira. São Paulo, Cia das Letras, 2018.

GRUBER, Jussara Gomes [org]. O livro das árvores. Benjamim Constant, Organização Geral dos Professores Ticuna Bilíngues, 1997.

HERZOG, Cecília P. Cidades para todos: (re)aprendendo a conviver com a natureza. Rio de Janeiro, Mauad, 2013

HUTCHINSON, Edward. O desenho no projeto da paisagem. Barcelona, Gustavo Gilli, 2012.

LYDIA, Laura. Ervas sp. São Paulo, Funarte, 2015

LORENZI, Harri. Árvores brasileiras - Volumes 1, 2 e 3. Nova Odessa, Plantarum, 2016. LORENZI, Harri. Flora Brasileira - Arecaceae (palmeiras). Nova Odessa, Plantarum, 2010. LORENZI, Harri, SOUZA, Hermes M. Plantas ornamentais no Brasil. Nova Odessa, Plantarum, 2001

MANCUSO, Stefano. Revolução das plantas: um novo modelo para o futuro. São Paulo, Ubu, 2019.

MOTTA, Flávio. Roberto Burle Marx e a nova visão da paisagem. São Paulo, Nobel 1986.

MUNARI, Bruno. Drawing a tree. Mantova, Corraini, 2014.

OLIVEIRA, Ana Rosa de. Gilles Clément e o jardim planetário. Vitruvius Arquitextos. São Paulo, ano 01, n. 002.03, jul. 2000. Disponível em < https://www.vitruvius.com.br/ revistas/read/arquitextos/01.002/997> Acesso em 15.10.2019

SEVCHENKO, Nicolau. O front brasileiro na guerra verde: vegetais, colonialismo e cultura. Revista da USP. São Paulo, n. 30, jun/ago 1996, p. 108-119.

SILVA, Ana Paula, SILVA, Maria Francilene, ROCHA, Francinalda, ANDRADE, Ivanilza. Aulas práticas como estratégia para o conhecimento da botânica no ensino fundamen tal. Holos. Natal, n. 8, jan. 2015, p. 68-79. Disponível em <http://www2.ifrn.edu.br/ojs/ index.php/HOLOS/article/view/2347> Acesso em 10.10.2019 
VALERY, Paul. Degas dança desenho. São Paulo, Cosacnaify, 2012.

VALERY, Paul. Degas, Manet, Morisot. New York, Pantheon Books, 1960

WANDERSEE, James, SCHUSSLER, Elisabeth. Preventing Plant Blindness. The American

Biology Teacher. Berkeley, Vol. 61, No. 2, Fev. 1999, p. 82-86. Disponivel em < https://

www.jstor.org/stable/4450624 > Acesso em 11.905.21. https://doi.org/10.2307/4450624

\section{Ana Carolina Carmona Ribeiro}

Universidade de São Paulo. Faculdade de Arquitetura e Urbanismo

Rua do Lago, 876 - Butantã

Instituto Federal de São Paulo

https://orcid.org/0000-0003-3785-1514

accribeiro@usp.br

Nota do Editor:

Recebido em: 24/02/2021

Aprovado em: 18/05/202

Revisão: RMO 